\title{
THE ATTITUDES OF STUDENTS TOWARDS THE USE OF ICT DURING THEIR STUDIES
}

\author{
Lazar Stošić ${ }^{\prime *}$, Samson O. Fadiya ${ }^{2}$ \\ ${ }^{1}$ College for Preschool Teachers, Aleksinac, Serbia \\ ${ }^{2}$ Girne American University, Turkey \\ * Correspondence author. E-mail: Istosic@vsvaspitacka.edu.rs
}

\section{Acknowledgments}

This paper wouldn't have been compiled together without the moral and intellectual support of Prof. Zafer Ağdelen, Girne American University, Turkey, to whom we express our infinite gratitude for his time and effort invested in us

The purpose of this study was to examine attitudes of students towards the use of ICT during their studies. The survey included 285 students from Girne American University, Turkey. The sample consists of the students from first to fourth grade. The scale consists of 45 claims and is intended for determining students' attitudes towards the use of ICT during their studies. Questionnaires were utilized to gather information on the attitudes of students towards the use of ICT during their studies. Information was broke down using SPSS statistical package (IBM SPS Statistics Version 20) and with Monte Carlo program for the parallel examination. The study established that students towards the utilization of ICT made the significant commitment to the students' academic performance. It is advanced that the discoveries of this study will be valuable to students to acquire knowledge into the ICT variables that influence students'scholastic execution and consequently enhance their academic performance.

Results indicate that after one year of the intervention, there were statistically significant differences between the two groups only in sight vocabulary (at kindergarten and grade 1) and in alphabet (kindergarten). In all other areas of language development, there were no statistically significant differences between the achievement scores of the two groups. Results show that students appear to react to the prerequisites of their courses, programs, and universities. In all cases, there is a reasonable relationship between the students' view of handiness on certain ICT assets the critical quantities of understudies are quick to see ICT misused in the educating and learning process. There is positively scope for further research to examine how ICT interfaces crosswise over various areas and how the cross-connection application impacts its utilization.

Keywords: attitudes of students, implementation of the ICT, ICT in education, impact of ICT in education, education, information technology in teaching, educating, learning, factor analysis, parallel analysis. 
For citation: Stošić L., Fadiya S. O. The attitudes of students towards the use of ICT during their studies. Russian Psychological Journal, 2017, V. 14, no. 1, pp. $135-148$.

Original manuscript received 12.12.2016

\section{Introduction}

Students constitute an outstanding group inside this social framework, and their viewpoints have essential influence in encircling the movement that happens in school settings. In reality, it has been contended that young people ought to be seen as active members in molding common and instructive procedures instead of saw as detached beneficiaries of them. Research has shown that, from an early age, young people are equipped for insightful and valuable investigation of their experience of learning in school and can remark on teaching methodologies and settings that are useful in their learning $[5,7]$.

There are numerous drivers for this movement, some of which identify with the encounters and ways of life of College University. Developed student, who are or may have been an invocation, are very prone to comprehend the significance of innovation for their future profession and will progressively hope to experience its utilization over all subjects in advanced education. Additionally, it is frequently anticipated that understudies will require more adaptable examples of participation as they attempt to adjust their studies against family needs and duties and gain the cash that they have to pay for their education training $[2,6]$. The application of educational technology enhances skills and cognitive characteristics and the question is whether teachers are trained to keep up with [8].

Discoveries likewise demonstrate that while limits between home information and school information are being dissolved, learners' experience of ICT tackles the other character contingent on the connection of its utilization. Furlong et al. (op cit) found that at home, young people tend to control their own particular time, how they utilize innovation and the substance of what they do. In school, be that as it may, the locus of control lies somewhere else; accentuation is on learning exercises managed by the educator, metered by timetable imperatives, intended to meet educational modules criteria and accomplishment targets required utilization of ICTs.

There are two aspects to the improvements in the use of ICT at colleges in Turkey. One is worried about the upgrade of routes in which 'educating related' exercises are performed [10]. Not very many students at a grounds based college will have much contention over the attractive quality for more efficient scholastic managerial capacities. The other perspective, the case for utilizing ICT to conveyor part address the instructive segments of a course is harder to 
contend. Notwithstanding the urgings of government about the significance of e-figuring out how to everybody or the abundantly high need to react to the changing circumstances of understudies by giving progressively adaptable courses, the inquiries of precisely why. Stošić \& Stošić, 2015 [9] presented that the teachers are professionally trained in the use of innovations in teaching, but they are not sufficiently trained in the use of the Internet in the education. Learning experiences can be represented through peers learning, so-called collaborative E-learning through virtual communities, wikis, forums, chat rooms, virtual worlds $[11,12,13]$. Also, how one ought to coordinate ICT into a current up close, and the private course is in some cases hard to reply [1, 3].

\section{Setting and design of the study}

In this study, we inspect the viewpoints of students in Four English free schools on the commitment of ICT to educating and learning. These schools were in exploration organization with the Girne American University, and they had recognized the utilization of ICT to bolster subject instructing and learning as a universal need for advancement. The opening (developmental) period of the following system of innovative work tried to distinguish and examine what educators and students saw as an active practice in utilizing ICT to bolster instructing. Moreover, learning, with a perspective to advising a second (formative) stage in which promising methodologies would be created and explored in more noteworthy profundity. In this particular study, we draw on interviews directed with students as a significant aspect of the opening period of the project, to investigate their experience of ICT in instructing and learning.

The paper is structured as follows: after the introductory part (section 1), section 2 present setting and design of the study, section 3 presents the materials and methods used in the preparation of the paper, set the main and auxiliary hypotheses, the nature and type of the sample and statistical test and the parameters used. Section 4 reveals the preliminary results of our research. Section 5 reveals discussions of our research. Conclusions are drawn in section 6 .

\section{Materials and methods}

This research was conducted with the aim to examine the attitudes of students towards the use of ICT during their studies and to try to give a recommendation for future strategy and implementation. The subject of this research is the attitudes of students towards the use of ICT during their studies. The aim of the research is reflected in the effort to examine the attitudes of students towards the use of ICT during their studies.

Hypothesis 1. It is assumed that the reliability of the rating scale as a whole is at a high level. 
Hypothesis 2. It is assumed that the instrument is valid, and the factors that will be extracted from the factor the analysis will be linked to attitudes of students towards the use of ICT during their studies.

Hypothesis 3. It is assumed that the use of ICT throughout the study adds a new dimension to the teaching process, which ICT is becoming an essential part of the process of instruction.

Hypothesis 4. It is assumed that the application of ICT ignores traditional teaching, which bridges the distance students and teachers where there are no face-to-face contacts.

Hypothesis 5. It is assumed that students ICT enables easier, faster and better learning in order easily and efficiently exchanging knowledge with other students.

The survey included 285 students from Girne American University, Turkey. The sample consists of the students from first to fourth grade. The scale consists of 45 claims and is intended for determining students' attitudes towards the use of ICT during their studies. The students have the opportunity to express the degree of disagreement with the above statements. The scale is based on the possibility of choosing among the complete agreement "Strongly agree", through partial "I agree", "Tend to agree", to complete negation "Do not agree", and "Strongly disagree".

The survey was conducted in Girne American University, Turkey. The sample included 285 students, 63 students from first grade $(22.1 \%), 65$ students from second grade $(22.8 \%), 74$ students from third grade $(26.0 \%)$ and 83 students from fourth grade $(29.18 \%)$.

\section{Statistical tests and parameters}

The data were analyzed with the IBM SPS Statistics, Version 20 and with Monte Carlo program for the parallel analysis. The data with a normal distribution were analyzed with the parametric test and the quantitative data without a normal distribution were analyzed with non-parametric tests, and Cronbach's Alpha was used to demonstrate the reliability and the internal approval of the scale for this sample. To analyze the normal distribution of the variables $(P>0.05)$ we used the Kolmogorov-Smirnov test. To determine whether the distribution can satisfy even the more stringent criteria of normality we used the Shapiro-Wilk test experiment was meant. The results are expressed as mean, standard deviation (SD) or $95 \%$ confidence interval $(95 \% \mathrm{Cl})$. With using the factor analyses we wanted to determine whether there is a smaller number of variables the factors that explain such interconnection. We tried to confirm the results obtained by the factor analysis with parallel analysis using the Monte Carlo program. The interconnection of variables was tested using the two-factor univariate ANOVA. 
The statistical analysis was conducted at $95 \%$ confidence level. A P value less than 0.05 was considered statistically significant.

\section{Results}

In our sample, the value of Cronbach's Alpha was 0.951. The value of the Kaiser-Meyer-Oklinovog indicators was 0.930 . Bartlett's test of sphericity in the chi-square test $\left(X^{2}=5545.774\right)$ and 990 (Table 1).

Table 1.

Results of the Kaiser-Meyer-Oklinovog and Bartlett's test

\begin{tabular}{|c|c|c|}
\hline \multicolumn{2}{|c|}{ Kaiser-Meyer-Olkin Measure of Sampling Adequacy } & 0.930 \\
\hline \multirow{3}{*}{ Bartlett's Test of Sphericity } & Approx. Chi-Square & 5545.774 \\
\cline { 2 - 3 } & $\mathrm{df}$ & 990 \\
\cline { 2 - 3 } & Sig. & .000 \\
\hline
\end{tabular}

The percentage of variance that is explained by the method of orthogonal varimax rotation, which shows how much variance is explained by individual factors, can be seen in Table 2 .

Total variance explained (Total Variance Explained)

\begin{tabular}{|c|c|c|c|c|c|c|c|c|c|}
\hline \multicolumn{8}{|c|}{$\begin{array}{c}\text { Total Variance Explained } \\
\text { Compo- } \\
\text { nent }\end{array}$} & \multicolumn{3}{|c|}{ Initial Eigenvalues } & \multicolumn{2}{c|}{$\begin{array}{c}\text { Extraction Sums of } \\
\text { Squared Loadings }\end{array}$} & \multicolumn{3}{|c|}{$\begin{array}{c}\text { Rotation Sums of } \\
\text { Squared Loadings }\end{array}$} \\
\cline { 2 - 12 } & Total & $\begin{array}{c}\text { \% of } \\
\text { Variance }\end{array}$ & $\begin{array}{c}\text { Cumu- } \\
\text { lative\% }\end{array}$ & Total & $\begin{array}{c}\text { \% of } \\
\text { Variance }\end{array}$ & $\begin{array}{c}\text { Cumul- } \\
\text { ative\% }\end{array}$ & Total & $\begin{array}{c}\text { \% of } \\
\text { Variance }\end{array}$ & $\begin{array}{c}\text { Cumu- } \\
\text { lative\% }\end{array}$ \\
\hline 1 & 14.430 & 32.068 & 32.068 & 14.430 & 32.068 & 32.068 & 6.319 & 14.043 & 14.043 \\
\hline 2 & 2.074 & 4.608 & 36.676 & 2.074 & 4.608 & 36.676 & 5.775 & 12.834 & 26.876 \\
\hline 3 & 1.811 & 4.025 & 40.701 & 1.811 & 4.025 & 40.701 & 3.663 & 8.139 & 35.015 \\
\hline 4 & 1.326 & 2.947 & 43.647 & 1.326 & 2.947 & 43.647 & 3.107 & 6.904 & 41.919 \\
\hline 5 & 1.297 & 2.883 & 46.531 & 1.297 & 2.883 & 46.531 & 2.075 & 4.611 & 46.531 \\
\hline 6 & 1.191 & 2.648 & 49.178 & & & & & & \\
\hline 7 & 1.178 & 2.618 & 51.796 & & & & & & \\
\hline 8 & 1.131 & 2.514 & 54.310 & & & & & & \\
\hline 9 & 1.038 & 2.307 & 56.617 & & & & & & \\
\hline 10 & 1.002 & 2.226 & 58.843 & & & & & & \\
\hline 11 & .988 & 2.195 & 61.038 & & & & & & \\
\hline 12 & .965 & 2.146 & 63.183 & & & & & & \\
\hline 13 & .932 & 2.071 & 65.254 & & & & & & \\
\hline 14 & .872 & 1.937 & 67.191 & & & & & & \\
\hline 15 & .832 & 1.849 & 69.040 & & & & & & \\
\hline
\end{tabular}


РОССИЙСКИЙ ПСИХОЛОГИЧЕСКИЙ ЖУРНАЛ • 2017 ТОМ 14 № 1

RUSSIAN PSYCHOLOGICAL JOURNAL・2017 VOL. 14 \# 1

\begin{tabular}{|c|c|c|c|c|c|c|c|c|c|}
\hline \multicolumn{10}{|c|}{ Total Variance Explained } \\
\hline \multirow{2}{*}{$\begin{array}{c}\text { Compo- } \\
\text { nent }\end{array}$} & \multicolumn{3}{|c|}{ Initial Eigenvalues } & \multicolumn{3}{|c|}{$\begin{array}{l}\text { Extraction Sums of } \\
\text { Squared Loadings }\end{array}$} & \multicolumn{3}{|c|}{$\begin{array}{l}\text { Rotation Sums of } \\
\text { Squared Loadings }\end{array}$} \\
\hline & Total & $\begin{array}{c}\text { \% of } \\
\text { Variance }\end{array}$ & \begin{tabular}{|c|} 
Cumu- \\
lative\%
\end{tabular} & Total & $\begin{array}{c}\% \text { of } \\
\text { Variance }\end{array}$ & \begin{tabular}{|l|} 
Cumul- \\
ative\%
\end{tabular} & Total & $\begin{array}{c}\% \text { of } \\
\text { Variance }\end{array}$ & \begin{tabular}{|l} 
Cumu- \\
lative\%
\end{tabular} \\
\hline 16 & .805 & 1.789 & 70.829 & & & & & & \\
\hline 17 & .748 & 1.661 & 72.491 & & & & & & \\
\hline 18 & .741 & 1.647 & 74.138 & & & & & & \\
\hline 19 & .708 & 1.573 & 75.711 & & & & & & \\
\hline 20 & .693 & 1.540 & 77.251 & & & & & & \\
\hline 21 & .661 & 1.468 & 78.719 & & & & & & \\
\hline 22 & .655 & 1.454 & 80.174 & & & & & & \\
\hline 23 & .595 & 1.323 & 81.497 & & & & & & \\
\hline 24 & .587 & 1.304 & 82.801 & & & & & & \\
\hline 25 & .547 & 1.215 & 84.016 & & & & & & \\
\hline 26 & .534 & 1.188 & 85.203 & & & & & & \\
\hline 27 & .513 & 1.139 & 86.342 & & & & & & \\
\hline 28 & .501 & 1.114 & 87.456 & & & & & & \\
\hline 29 & .466 & 1.035 & 88.491 & & & & & & \\
\hline 30 & .445 & .989 & 89.479 & & & & & & \\
\hline 31 & .429 & .954 & 90.433 & & & & & & \\
\hline 32 & .425 & .944 & 91.377 & & & & & & \\
\hline 33 & .407 & .904 & 92.281 & & & & & & \\
\hline 34 & .388 & .862 & 93.143 & & & & & & \\
\hline 35 & .358 & .796 & 93.940 & & & & & & \\
\hline 36 & .346 & .768 & 94.708 & & & & & & \\
\hline 37 & .336 & .747 & 95.455 & & & & & & \\
\hline 38 & .316 & .703 & 96.158 & & & & & & \\
\hline 39 & .288 & .641 & 96.799 & & & & & & \\
\hline 40 & .275 & .610 & 97.409 & & & & & & \\
\hline 41 & .252 & .561 & 97.970 & & & & & & \\
\hline 42 & .246 & .547 & 98.517 & & & & & & \\
\hline 43 & .231 & .513 & 99.030 & & & & & & \\
\hline 44 & .229 & .509 & 99.539 & & & & & & \\
\hline 45 & .207 & .461 & 100.000 & & & & & & \\
\hline \multicolumn{10}{|c|}{ Extraction Method: Principal Component Analysis } \\
\hline
\end{tabular}

The parallel analysis was performed using the Monte Carlo PCA for Parallel Analysis program (Table 3 ) for further confirmation of the factor analysis and the determining of the number of factors, and the results were compared with the results obtained in SPSS (Table 2). 
Table 3.

Comparison of characteristic values obtained by PCA and threshold values obtained by parallel analysis

\begin{tabular}{|c|c|c|c|}
\hline $\begin{array}{c}\text { Sequence number } \\
\text { of components }\end{array}$ & $\begin{array}{c}\text { The characteristic } \\
\text { actual values of } \\
\text { PCA }\end{array}$ & $\begin{array}{c}\text { Values obtained by } \\
\text { parallel analysis }\end{array}$ & Decision \\
\hline 1 & 14.430 & 1.8565 & Accept \\
\hline 2 & 2.074 & 1.7617 & Accept \\
\hline 3 & 1.811 & 1.6944 & Accept \\
\hline 4 & 1.326 & 1.6359 & Do not accept \\
\hline 5 & 1.297 & 1.5833 & Do not accept \\
\hline
\end{tabular}

The analysis of Cattell's landslides methods, i. e. saddle diagrams (Scree Plot) the existence of a clear point of fracture after the third factor was established.

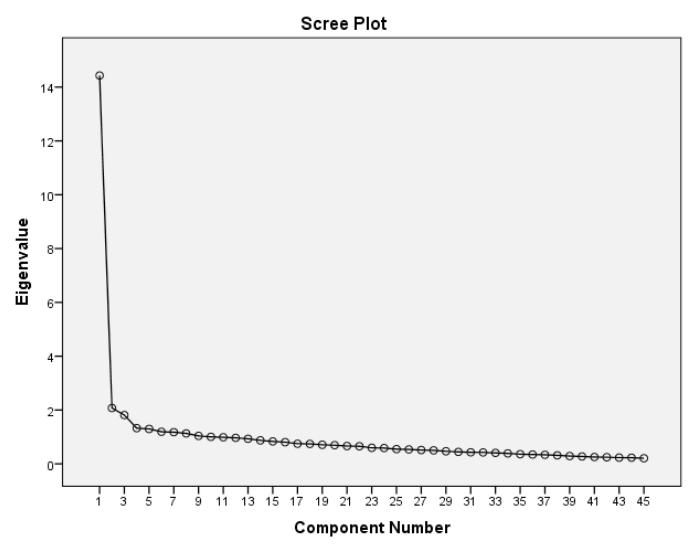

Figure 1. Number of factors according to Cattell's landslide method (Scree Plot)

With the use of two-factor univariate ANOVA, the interconnection of variables (such as gender and years of study) was tested, about the opinion of the attitudes of students towards the use of ICT during their studies.

We also wanted to know whether the difference of years of study can influence the attitudes of students towards the use of ICT during their studies (Table 4). 


\section{Tests of Between-Subjects Effects}

Table 4.

\begin{tabular}{|c|c|c|c|c|c|c|}
\hline \multicolumn{7}{|c|}{$\begin{array}{c}\text { Dependent Variable: The application of ICT in faculty becomes an integral part of } \\
\text { the teaching process of education and learning }\end{array}$} \\
\hline Source & $\begin{array}{l}\text { Type III } \\
\text { Sum of } \\
\text { Squares }\end{array}$ & $d f$ & $\begin{array}{l}\text { Mean } \\
\text { Square }\end{array}$ & $F$ & Sig. & $\begin{array}{l}\text { Partial Eta } \\
\text { Squared }\end{array}$ \\
\hline $\begin{array}{l}\text { Corrected } \\
\text { Model }\end{array}$ & $7.507^{\mathrm{a}}$ & 7 & 1.072 & 1.035 & .407 & .025 \\
\hline Intercept & 3652.739 & 1 & 3652.739 & 3525.398 & .000 & .927 \\
\hline Gender & .000 & 1 & .000 & .000 & .983 & .000 \\
\hline YS & 4.579 & 3 & 1.526 & 1.473 & .222 & .016 \\
\hline Gender * YS & 4.375 & 3 & 1.458 & 1.408 & .241 & .015 \\
\hline Error & 287.005 & 277 & 1.036 & & & \\
\hline Total & 4372.000 & 285 & & & & \\
\hline $\begin{array}{l}\text { Corrected } \\
\text { Total }\end{array}$ & 294.512 & 284 & & & & \\
\hline \multicolumn{7}{|c|}{ a. $\mathrm{R}$ Squared $=.025$ (Adjusted R Squared $=.001$ ) } \\
\hline
\end{tabular}

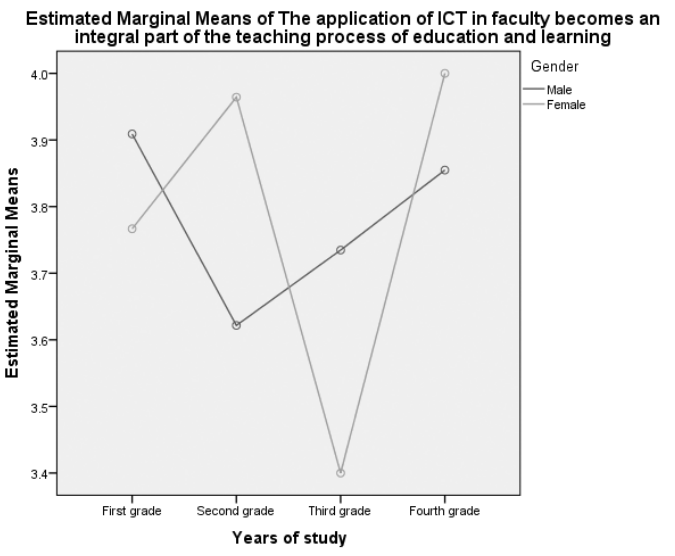

Figure 2. Estimated marginal means of the application of ICT in faculty becomes an integral part of the teaching process of education and learning 
Tests of Between-Subjects Effects

Table 5.

\begin{tabular}{|c|c|c|c|c|c|c|}
\hline \multicolumn{7}{|c|}{$\begin{array}{c}\text { Dependent Variable: The application of ICT bridging the distance between students } \\
\text { and professors, due to their remoteness from each other }\end{array}$} \\
\hline Source & $\begin{array}{l}\text { Type III } \\
\text { Sum of } \\
\text { Squares }\end{array}$ & $d f$ & $\begin{array}{l}\text { Mean } \\
\text { Square }\end{array}$ & $F$ & Sig. & $\begin{array}{l}\text { Partial Eta } \\
\text { Squared }\end{array}$ \\
\hline $\begin{array}{l}\text { Corrected } \\
\text { Model }\end{array}$ & $11.021^{\mathrm{a}}$ & 7 & 1.574 & 1.353 & .225 & .033 \\
\hline Intercept & 3042.886 & 1 & 3042.886 & 2615.276 & .000 & .904 \\
\hline Gender & 5.256 & 1 & 5.256 & 4.517 & .034 & .016 \\
\hline YS & 3.333 & 3 & 1.111 & .955 & .415 & .010 \\
\hline Gender * YS & 1.929 & 3 & .643 & .553 & .647 & .006 \\
\hline Error & 322.291 & 277 & 1.164 & & & \\
\hline Total & 3662.000 & 285 & & & & \\
\hline $\begin{array}{l}\text { Corrected } \\
\text { Total }\end{array}$ & 333.312 & 284 & & & & \\
\hline \multicolumn{7}{|c|}{ a. R Squared $=.033$ (Adjusted R Squared $=.009$ ) } \\
\hline
\end{tabular}

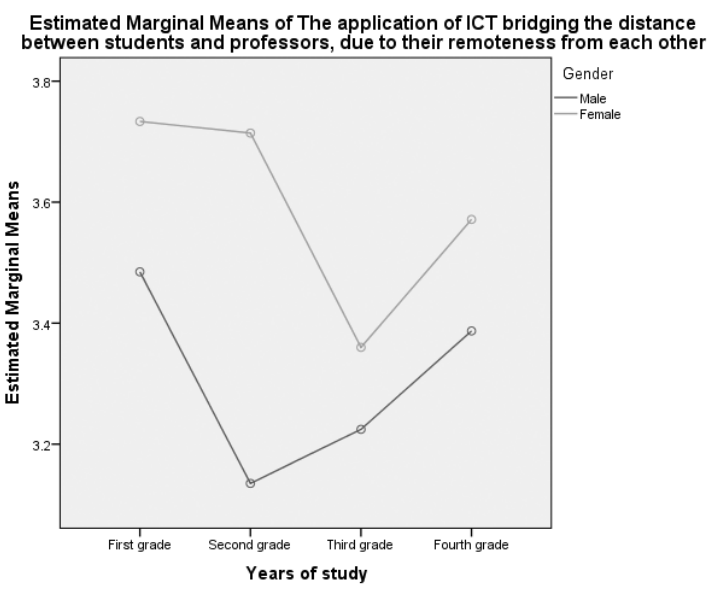

Figure 3. Estimated marginal means of the application of ICT bridging the distance between students and professors, due do their remoteness from each other 
Table 6.

Tests of Between-Subjects Effects

\begin{tabular}{|c|c|c|c|c|c|c|}
\hline \multicolumn{7}{|c|}{$\begin{array}{c}\text { Dependent Variable: Use of ICT enables easier, faster and better acquiring } \\
\text { knowledge }\end{array}$} \\
\hline Source & $\begin{array}{l}\text { Type III } \\
\text { Sum of } \\
\text { Squares }\end{array}$ & $d f$ & $\begin{array}{l}\text { Mean } \\
\text { Square }\end{array}$ & $F$ & Sig. & $\begin{array}{l}\text { Partial Eta } \\
\text { Squared }\end{array}$ \\
\hline $\begin{array}{l}\text { Corrected } \\
\text { Model }\end{array}$ & $15.886^{a}$ & 7 & 2.269 & 2.063 & .048 & .050 \\
\hline Intercept & 3364.579 & 1 & 3364.579 & 3058.600 & .000 & .917 \\
\hline Gender & 4.845 & 1 & 4.845 & 4.405 & .037 & .016 \\
\hline YS & 10.870 & 3 & 3.623 & 3.294 & .021 & .034 \\
\hline Gender * YS & 1.186 & 3 & .395 & .359 & .782 & .004 \\
\hline Error & 304.711 & 277 & 1.100 & & & \\
\hline Total & 4007.000 & 285 & & & & \\
\hline $\begin{array}{l}\text { Corrected } \\
\text { Total }\end{array}$ & 320.596 & 284 & & & & \\
\hline \multicolumn{7}{|c|}{ a. R Squared $=.050$ (Adjusted R Squared $=.026$ ) } \\
\hline
\end{tabular}

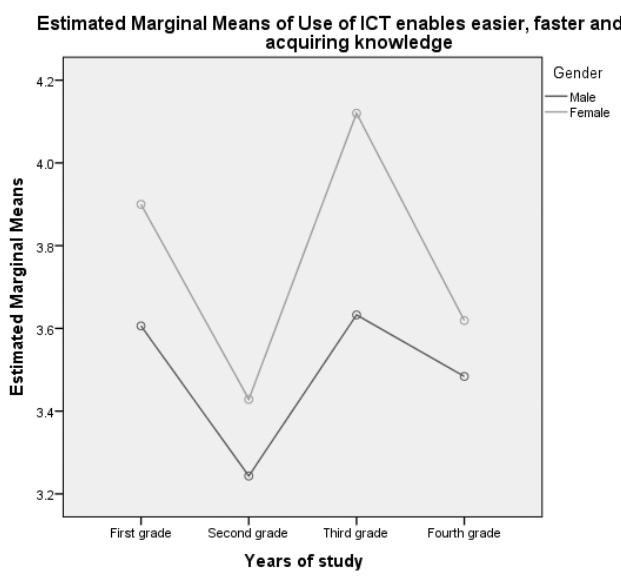

Figure 4. Estimated limited means of use of ICT enables easier, faster and better acquiring knowledge 


\section{Discussion}

The purpose of this study was to show the attitudes of students towards the use of ICT during their studies. In our sample of 285 (100\% valid sample) respondents, the value of Cronbach alpha coefficient (Cronbach's Alpha $=0.951$ ) showed magnificent reliability and internal approval of the scale for this sample, which meets the criteria of reliability. The scale has good internal approval, Cronbach alpha coefficient of 0.951 . The results of Kolmogorov-Smirnov's and Shapiro-Wilk's test show that the distribution of the results obtained by the scale is established at the level of significance $p=0.001$ for all 45 claims, which further means that our results meet even the more stringent criteria of the normality of the distribution curvature.

Our scale with 45 statements was subjected to the principal component analysis (PCA) in SPSS program. Before the implementation of the PCA program, the suitability of data for factor analysis was estimated. While examining the correlation matrix, a lot of the coefficients of 0.3 value or more have been discovered. The value of the Kaiser-Meyer-Oklinov's (KMO) indicators was 0.930, which exceeds the recommended value of 0.6. Bartlett's test of sphericity in the chi-square test $\left(X^{2}=5545.774\right)$ and 990 degrees of freedom $(\mathrm{df}=990)$ reached statistical significance at the level of $p<0.001(p=0.000)$, which points to a matrix factorization of the justification of the factor analysis.

The results of the parallel analyzes (Table 3) show that the value of 1.6359 obtained by parallel analysis is higher than the actual characteristic values from PCA 1.326, which is why this factor is not accepted. The results of the parallel analysis give us the conclusion that we should keep the three factors. The analysis of the saddle diagram (Figure 1) confirmed the existence of a clear point of fracture after the three components. Relying on the Cattell criteria, it was decided to keep the three elements for further exploration.

In Table 4, we see different groups studied the effect of gender and years of study to claim "The application of ICT and faculty becomes an integral part of the teaching process of education and learning", measured on a scale Life Orientation Test (LOT). The subjects were divided into four (Group 1: The first year of study, Group 2: second-year student, Group 3: the third year of studies and Group 4: the fourth year of study). From Levene's Test of Equality of Error Variances, we can see that the Sig. $=0.122$, which indicates that the homogeneity of variances is not affected, i. e., that the variance of the dependent variable is equal in all the groups. The effect of the interaction between gender and year of study was not statistically significant, $F(1,408)=.241$. Subsequent comparisons using Tukeje's HSD test showed that the mean value of the male population $(M=3.78, S D=.962)$ was not significantly different from the female population $(M=3.78, S D=1.114)$. From the results it can be concluded that there are no significant main effects 
of gender (Sig. $=.983$ ), but even exist a significant main effect according to the years of study (Sig. $=.222$ ). This means that the effect does not vary by age according to the claim, but there is a difference in the levels of thinking according to gender (Figure 2). Because the application of ICT and faculty becomes an integral part of the teaching process of education and learning the statement of Stošić \& Stošić, 2015 [9] is confirmed that the teachers have to be professionally trained in the use of innovations in teaching.

In Table 5, we see different groups studied the effect of gender and years of study to claim "The application of ICT bridging the distance between students and professors, due to their remoteness from each other", measured on a scale Life Orientation Test (LOT). From Levene's Test of Equality of Error Variances, we can see that the Sig. $=0.689$, which indicates that the homogeneity of variances is not affected, i. e., that the variance of the dependent variable is equal in all the groups. The effect of the interaction between gender and year of study was not statistically significant, $F(0,553)=.647$. A statistically significant main effects of gender $F(4.517)=.034$; however, the impact is small (Partial Eta Squared $=.006$ ). Subsequent comparisons using Tukeje's HSD test showed that the mean value of the male population $(M=3.31, S D=1.097)$ was not significantly different from the female population ( $M=3.61, S D=1.037)$. From the results, it can be concluded that there was a significant main effect of sex (Sig. $=0.034$ ), but no significant main effect according to the years of study (Sig. $=0.415$ ). These results confirm the statement E. Kurilovas et al., 2014 [4] that teachers can come into a situation that they are not trained for personalized aspect of E-learning, where students can learn independently. Also, results from authors [11, 12, 13] confirm that collaborative E-learning through virtual communities, wikis, forums, chat rooms, virtual worlds bridging the distance between students and professors, due to their remoteness from each other.

In Table 6, we see different groups studied the effect of gender and years of study to claim "Use of ICT enables easier, faster and better acquiring knowledge", measured on a scale Life Orientation Test (LOT). From Levene's Test of Equality of Error Variances, we can see that the Sig. $=0.108$, which indicates that the homogeneity of variances is not affected, i. e., that the difference in the dependent variable is equal in all the groups. The effect of the interaction between gender and year of study was not statistically significant, $F(.359)=.782$. A statistically significant main effects of gender $F(4,405)=.037$; however, the impact is small (Partial Eta Squared $=.016$ ). Also, there were a statistically significant main effect years of study $F(3,294)=.021$; however, the impact is small (Partial Eta Squared $=.034$ ). Subsequent comparisons using Tukeje's HSD test showed that the mean value of the male population ( $M=3.50, S D=1.073$ ) was not significantly different from the female population ( $M=3.77, S D=1.026)$. From the results, it 


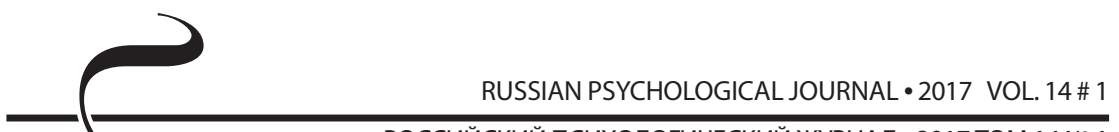

РОССИЙСКИЙ ПСИХОЛОГИЧЕСКИЙ ЖУРНАЛ • 2017 ТОМ 14 № 1

can be concluded that there was a significant main effect of gender (Sig. $=.037$ ), but no significant main effect according to the years of study (Sig. $=.021$ ). This means that the effect does not vary by age according to the claim, but there is a difference in the levels of thinking according to gender (Figure 4).

\section{Conclusions}

In conclusion, although access to and utilization of ICT is across the board, the impact of college model is by all accounts a critical variable to consider the record. For scholarly purposes, students appear to react to the prerequisites of their courses, programs, and universities. In all cases, there is a reasonable relationship between the students' view of handiness on certain ICT assets the critical quantities of understudies are quick to see ICT misused in the educating and learning process. Be that as it may, the same students are extremely hesitant to see up close and personal contact supplanted with online options. The significance of the work setting as a driver for ICT utilization proposes that specializes ought to likewise strengthen the routes in which specific advancements can expand adequacy in practice settings, and additionally course ponder.

There is positively scope for further research to examine how ICT interfaces crosswise over various areas and how the cross-connection application impacts its utilization. These innovations turn out to be perpetually coordinated in the day by day lives amid work, study and relaxation, so understanding client impression of ICT ought to give enhanced execution and acknowledgment of as of now creating advances.

In another word, the outcomes acquired can't support the possibility of internet learning situations being better than mixed learning situations as far as improvement of students' computerized skill, as more research ought to be completed into the instructive model utilized as a part of the distinctive colleges. Be that as it may, they do lead us to propose the need to consider that innovation rich learning situations cultivate students' digital skills (and not the other path round). In particular, it appears that we should not depend on students' digital skills to encourage ICT supported learning operations at the University.

\section{References}

1. Butler D. L., \& Sellbom M. Barriers to adopting technology. Educause Quarterly, 2002, 2, pp. 22-28.

2. Butzin S. M. Using instructional technology in transformed learning environments: An evaluation of Project CHILD. Journal of Research on Computing in Education, 2001, 33 (4), pp. 367-373.

3. Darling L. Your ELearning Strategy: Make sure it's learning for results. Training, 2002, 39 (3), p. 2. 
4. Kurilovas E., Kubilinskiene S., \& Dagiene V. Web 3.0-Based personalisation of learning objects in virtual learning environments. Computers in Human Behavior, 2014, 30, pp. 654-662.

5. McCallum B., Hargreaves E., \& Gipps C. Learning:The pupil's voice. Cambridge Journal of Education, 2000, 30 (2), pp. 275-289.

6. Reiser R. A. A history of instructional design and technology: Part I: A history of instructional media. Educational technology research and development, 2001, 49 (1), pp. 53-64.

7. Rudduck J., \& Flutter J. Pupil participation and pupil perspective: 'carving a new order of experience'. Cambridge Journal of Education, 2000, 30 (1), pp. 75-89.

8. Stošić L. The importance of educational technology in teaching. International Journal of Cognitive Research in Science, Engineering and Education (IJCRSEE), 2015, 3 (1), pp. 111-114. Available at: http://ijcrsee.com/index.php/ijcrsee/ article/view/166/316 (accessed 20.06.16)

9. Stošić L, Stošić I. Perception of teachers regarding the implementation of the internet in education. Computers in Human Behavior, 2015, 53. doi:10.1016/j.chb.2015.07.027

10. Thomas P. The evaluation of electronic marking of examinations. ACM SIGCSE Bulletin, 2003, 35 (3), pp. 50-54.

11. Zhang J. X., Liu L., Ordonez de Pablos P., \& She J. The auxiliary role of information technology in teaching: Enhancing programming course using Alice. International Journal of Engineering Education, 2014, 30 (3), pp. 560-565.

12. Zhang J. X., Zhang H., Ordóñez de Pablos P., \& Sun Y. Challenges and foresights of global virtual worlds markets. Journal of Global Information Technology Management, 2014, 17 (2), pp. 69-73.

13. Zhang X., Ma H., Wu Y., Ordonez de Pablos P., \& Wang W. Applying cloud computing technologies to upgrade the resource configuration of laboratory course: The case of quality engineering education platform. International Journal of Engineering Education, 2014, 30 (3), pp. 596-602. 